SAD / JSR

Sosyoloji Araştırmaları Dergisi / Journal of Sociological Research

Cilt / Volume 22 Sayı / Number 1 (Nisan / April 2019) : (32-68)
Araştırma Makelesi / Research Article

Geliş Tarihi / Submited: 19.10.2018

Kabul Tarihi / Accepted: 11.01.2019

\title{
YAŞAM KOŞULLARI VE SAĞLIK HASTALIK ALGILARI
}

\section{Kemal AYDIN 1}

\section{ÖZ}

$\mathrm{Bu}$ makalede fertlerin subjektif algılarına dayalı sağlık durumları, kronik hastalıklar ve sağlık sorunları nedeni ile günlük faaliyetlerde aksama gibi değişkenler analiz edilerek Türkiye, Avrupa Birliği ve OECD ülkelerinde sağlık-hastalık durumu ve algıları incelenmektedir. TÜİK ve EUROSTAT’ın 2006-2016 yılları arasında yaptığı Gelir ve Yaşam Koşulları Araştırması'nın verileri ve OECD’nin daha iyi yaşam endeksi verileri kullanılmıştır. İncelenen ülkelerde üç değişken açısından yaygınlık oranları değerlendirildiğinde sağlık-hastalık durumlarının birbirine yakın olduğu görülmektedir. Türkiye, Avrupa Birliği ve OECD ülkelerinde insanların yaklaşık \%30-32'si sağlık sorunu olduğunu rapor ederken \%65-70 oranında bir kitle sağlık durumunun "iyi” olduğunu belirtmiştir. Sağlık durumu algılarında Türkiye ortalamaları kır-kent, cinsiyet, medeni durum, gelir ve eğitim düzeyine göre detaylandırıldığında pozitif sağlık algılarına etki eden en önemli faktörler sırası ile medeni durum, eğitim seviyesi ve gelir düzeyidir.

Anahtar Kelimeler: Sağlık Sosyolojisi, Halk Sağlığı, Sağlık Durumu, Kronik Hastalıklar, Günlük Faaliyetlerde Sınırlanma, Türkiye, Avrupa Birliği ve OECD

${ }^{1}$ Doç. Dr., Kocaeli Üniversitesi İ̈BF, Siyaset Bilimi ve Kamu Yönetimi Bölümü 


\title{
LIVING CONDITION, SELF PERCEIVED HEALTH AND ILLNESS
}

\begin{abstract}
Individuals sampled from Turkey, Europe and OECD countries are assessed for subjective perceptions of their health status, prevalence of self reported chronic disease and limitation in daily activities due to health problems. Income and Living Conditions and better life index data were used for the analyses. The results showed that the rate of health conditions, chronic illness and limitation in daily activities in the respective countries were quite similar. Between 2006 and 2016, results for sampled countries showed 30-32\% of people on average stated that they had chronic illness and $65-70 \%$ of them stated that their health status was good.The rate of health status perception and chronic diseases patterns in EU, OECD and Turkey were relatively similar. Furthermore, health and disease perception in Turkey were examined by rural-urban, gender, marital status, income and educational level, the most important factors affecting positive health perceptions were marital status, educational and income level respectively.
\end{abstract}

Key Words: Sociology of Health, Public Health, Health Status, Chronic Deseases, Limitation in Daily Activities, Turkey, European Union and OECD 


\section{GİRIŞ}

İnsan hayatının en önemli meselelerinden biri de sağlıktır. Bu nedenle, günümüzde sağlık ve hastalık sadece tıbbın konusu olmaktan çıkmış ve en az biyolojik faktörler kadar toplumsal yapı ile ilişkili olduğu da bilinmektedir. Sağlık sosyologları, epidemiyologlar ve halk sağlığı uzmanları sağlık ve hastalığın sosyokültürel sebeplerini araştırmakta ve hastalıkların daha iyi anlaşılarak kontrol altına alınmasında çalışmalar yapmaktadır.

Bu çalışmada Türkiye İstatistik Kurumu (TÜİK) ve Avrupa İstatistik Kurumu (EUROSTAT)'nun Gelir ve Yaşam Koşulları anketlerinde fertlerin subjektif algılarına dayalı sağlık durumları, kronik (müzmin) hastalıklar, herhangi bir sağlık sorunu nedeni ile günlük faaliyetlerde aksama gibi değişkenler sosyo kültürel faktörlerle ilişkileri bağlamında analiz edilerek Türkiye, Avrupa Birliği ve OECD ülkelerinde sağlık-hastalık durumu ve algıları mukayese edilmektedir.

Makalenin ilk bölümünde konu ile ilgili yapılan araştırmalara değinilmekte ve sağlık-hastalığın toplumsal kökenleri ile ilgili araştırma sonuçları özetlenerek, objektif ve subjektif sağlık-hastalık ölçümleri üzerinde durulmaktadır. İkinci bölümde veriler ve yöntem açıklanmakta ve son bölümde analizler özetlenerek Türkiye, Avrupa Birliği ve OECD’ye üye ülkelerde sağlık-hastalık durumu ve algıları değerlendirilmektedir. Sağlık ve hastalık durumlarının sosyolojik değişkenlerle ilişki düzey ve eğilimini saptamak sağlık sosyolojisi, epidemiyoloji, halk sağlı̆̆ı ve sağlık politikaları bakımından katkı sağlamayı amaçlamaktadır.

\section{SAĞLIK VE HASTALIĞIN TOPLUMSAL KÖKENLERİ}

Sağlığın tanımını yapmak oldukça zordur. "Sağlık bir bilimsel bilgi, bir fikir değil, fonksiyon görmekte olan bir bedenin dilidir'. Son yıllara kadar sağlık, 'hastalık ve sakatlığın olmayışı', hastalık da 'sağlıklı olmama' gibi dar bir çerçeve içinde tanımlandığından bu tanımların bireyi etkileyen ruhsal ve sosyal faktörleri önemsemediğini düşündürmüştür” (İnanç ve diğ. 1999) Oysa sağlık çeşitli faktörlerden 
etkilenmektedir. Bu faktörler sosyal, kültürel, ekonomik, fiziksel ve biyolojik olarak gruplandırılır (Marmot ve Wilkinson, 1999; Bolsoy ve Sevil, 2006; Goryakin Suhrcke ve diğ, 2013; Aytaç ve Kurdaş, 2015).

Dünya Sağlık Örgütü, sağlığı “sağl1k yalnızca hastalık ve sakatlığın olmayışı değil fiziksel, sosyal ve mental yönden tam bir iyilik halidir” şeklinde tanımlamaktadır. Bu tanım kapsamlı gibi gözükse de "iyilik hali” (well being) kişiden kişiye ve toplumdan topluma değişebilir. "Hastalık" kavramından da herkesin aynı şeyi anladığ 1 sanılır; oysa hastalığın tanımı da kişiden kişiye ve toplumdan topluma farklılık arz edebilir. Dolayısı ile hastalık durumu da yalnızca bir hastalığın rahatsızlığın olması ile açıklanamaz. Hastalık anormal bir durum olup, bireyin, fiziksel, ruhsal, zihinsel ve sosyal fonksiyonlarını daha önceki hale göre azaltır ya da iyice tüketir (Blaxter, 2004; Bolsoy ve Sevil, 2006).

Sağlık sosyolojisi ve sağlık-hastalık araştırmaları Türkiye'de yeni olmakla birlikte bu alanda yapılan çalışmalar her geçen yıl artmaktadır. Sağlık sosyolojisi alanında yapılan araştırmalara değinildiğinde “sağlık-hastalık problemini sosyal yönden araştırılması” (Türkdoğan, 1966); "sağlık - hastalık”, “güncel sosyal sorunlar ve sağlık” (Kasapoğlu 2001, 2008); “bebek ölümlerini etkileyen faktörler” (Akşit ve Akşit, 1989); “sağlık sistemi” (Kızılçelik, 1996); “Türkiye'de sağlık politikaları”, “sağlık sosyolojisi” (Kasapoğlu, 1999; Cirhinlioğlu, 2012; Tecim, 2016); “ekonomik ve sosyolojik bakış açısı ile hastalık ve sağlık" (Baloğlu, 2006; sağlık sosyolojisi, kadın ve kentleşme (Adak, 2002) ve "Türkiye'de sağlık sosyolojisi çalışmaları" (Güven, 2014) öne çıkan çalışmalardan bazılarıdır. Ayrıca, tıp hekimleri de sağlık politikaları, doktor-hasta ilişkileri, özel sermaye ve tıp gibi konularda çalışmalar yapmaktadır (Küçükusta, 2011).

Bu konularda yapılan uluslararası çalışmalara bakıldığında çok fazla proje, makale ve kitabın dökümünü yapmak zorlaşmaktadır. Avrupa ülkeleri söz konusu olduğunda gelir, eğitim düzeyi, çalışma şartlarının düzelmesi ve sağlık harcamalarındaki aşırı artışa rağmen sağlıkta eşitsizlik yaşam koşullarına bağlı olarak 
hala bütün ülkelerde kalıcı olmaya devam etmektedir (Dahlgren ve Whitehead, 1991; Wilkinson, 1997, Brown, 2006; Gataulinas ve Bancevica 2014; Matrai, 2015; Maheswaran ve diğ. 2015).

Son yıllarda sağlık sosyologları ve epidemiyologlar yayınladıkları çok sayıda makale ve kitapta sağlık ve hastalığ1 etkileyen sosyal yapıların varlığına değinmektedir (Marmot ve Wilkinson, 1999; Özen, 1993; Palloni, Aquirre ve diğ, 2002; Giddens, 2005; Aytaç ve Kurdaş, 2015; Adak, 2015; Alptekin, 2018). Geçtiğimiz yüzyılda halk sağlığındaki büyük ilerlemelere rağmen sağlık ve hastalığın genel nüfus içinde eşit bir biçimde dağılmadığını işaret etmektedir. Aslında sağlık-hastalık ve ölümlere dair söz konusu göstergeler, sağlığı etkileyen esaslı faktörün biyolojik yapımızdan çok toplumsal yapı ve koşullar olduğunu ortaya koymaktadır (Aytaç ve Kurdaş, 2015; Alptekin, 2018; Adak 2015, 2018). Araştırmalar bazı grupların diğerlerine göre daha sağlıklı olduğuna işaret etmektedir. Bu durum toplumların sosyo-ekonomik yapıları ile ilişkilidir. Uluslararası yapılan araştırmalarda ortaya çıkan sonuç gelir düzeyi, eğitim durumu, cinsiyet, yaşanılan yer, medeni durum, meslek, aile yapısı, gıda alışkanlıkları, sağlık bilgisi, genel sağlık politikaları, kültüre bağlı stres gibi sosyo-ekonomik faktörlerin sağlık ve hastalık dağglımında etkili olduğunu göstermektedir (Dahlgren ve Whitehead, 1991; Wilkinson, 1997; Gönç, 2013; Alptekin, 2018).

Ekonomik durum ve sağlık-hastalık arasındaki ilişki her yerde aynı sonucu vermektedir. Gelir düzeyi düşük ve yoksul olan bireyler daha çok hastalanmakta ve hastalık süreleri uzun sürmektedir. Zengin ülkelerde doğumda beklenen yaşam süresi çok daha uzundur. Yoksulluk beslenme bozukluğuna, hastalıkların sıklaşmasına, bireyin gelirinin çoğunun tedaviye ayrılmasına ve dönerek yoksulluğa yol açmaktadır. Yoksulların kötü ve yetersiz koşullarda çalışmaları ve barınmaları sağlık risk ve sorunlarının artmasına neden olur. Yoksulluk bireylerde psikolojik baskıya, kronik strese ve depresyona yol açar (Çukur ve Bekmez, 2012; Browne, 2014; Brown, 2006; Şantas, 2017; Tan, Shi ve diğ, 2018). Ancak, zengin ya da yoksul hangi ülkelerde olursa olsun her yerde insanlar hastalanmaktadır. Yüksek gelirli ülkelerde bazı kronik hastalıklar düşük gelirli ülkelere nispetle birbirine yakın ve hatta daha fazladır. Örneğin, 330 milyon 
nüfuslu Amerika'da 100 milyondan fazla insan ciddi bir kronik hastalık olan diyabet ve diyabet öncesi yüksek risk altında yaşamaktadır (Center for Desease Control and Prevention, 2017).

Kırsal ve kentsel bölgelerde iklim, nüfus yoğunluğu, yaşam koşullarının farklılığı bireylerin sağlık durumları üzerinde oldukça etkilidir. Kırsal bölgelerde gelir düşük ve sağlık hizmetlerine erişim kentlere göre kısıtlıdır. Kır ve kentlerdeki yaşam farklılıkları çoğunlukla sağlık ve hastalıklarda da kendini göstermektedir (Türkkan ve Aytekin, 2009; Manavgat ve Çelik, 2017; Alptekin, 2018).

Bazı nicel sağlık göstergelerini cinsiyete göre karşılaştırmak mümkündür. Kadınların ortalama yaşam beklentisi gelişmişlik düzeyi farklı ülkelerde erkeklerin ortalama değerlerinden daha uzundur. Ancak bu kadınların erkeklerden daha sağlıklı olduğu anlamına gelmemektedir. Kadınlar daha çok hastalanmakta ve sağlık kurumlarına başvurmaktadır (Adak, 2002).

Araştırmalarda ortaya çıkan bir diğer faktör de eğitim düzeyidir. Eğitim düzeyi yüksek bireyler, daha az işsiz kalmakta ve ekseriyetle iyi gelir getiren, sosyal güvenceli ve yüksek standartlı mesleklerde çalışmaktadır. Bu bağlamda eğitimli kişiler daha sağlıklı bir yaşam tarzına sahiptir. Daha çok spor yapmaya eğilimlidir, sağlıklı gıda alma olanakları daha fazladır; düzenli ve dengeli beslenme konusunda daha bilinçlidirler (Alptekin, 2018).

Fertlerin evli, bekâr, dul veya boşanmış olması ile çocuk sahibi olup olmaması da bir diğer önemli unsurdur. Bu görüş evli olanların hastalıklara yakalanma risklerinin daha az olduğunu, hastalıklara yakalandıklarında daha çabuk iyileştiklerini savunmaktadır. Evli fertler bekâr olanlara, dul ve boşanan bireylere göre daha sağlıklı olmaktadır (Kaisla vd; 2006; Alptekin, 2018; Terceira ve McQuillan, 2018). Ancak, diğer bazı araştırmaların bulgularına göre evli bireylerin sağlık durumlarında pozitif yönde cevap verme eğiliminde olduklarını ve ölüm oranlarında bekâr, boşanmış, ayrı yaşayan ve dul bireyler ile herhangi bir farkın olmadığını ifade etmektedirler (Hui, Z. vd., 2013).

$\mathrm{SAD} / \mathrm{JSR}$

Cilt / Volume 22 Sayı / Number 1 
Yukarıda kısaca özetlenen hususlar daha çok uluslararası araştırma sonuçlarını kapsamaktadır. Öte yandan ülkemizde sağlık sosyolojisi alanında bir hayli teorik araştırmalar ve saha araştırmaları olmasına rağmen sağlık-hastalık algıları ile ilgili saha araştırmaları dışında geniş ölçekli veri setleri ile epidemiyolojik tahlillerin yapılması gerekmektedir. Bu türden sağlık hastalık algıları OECD tarafından "daha iyi yaşam endeksi” kapsamında araştırılıp yayınlanmaktadır. Aynı şekilde EUROSTAT, üye ülkeler ile üyelik müzakeresinde bulunan ülkelerde yaşam kalitesi, yoksulluk, gelir dağılımı ve dışlanmanın boyutlarını ölçmek maksadı ile Gelir ve Yaşam Koşulları Anketi geliştirmiştir. Bu anketler ayrıca sağlık ve hastalık durumları ile ilgili verileri de kapsamaktadır. Türkiye' de de 2006 yılından beri aynı anket kesit ve panel araştırmalar şeklinde yapılmaktadır.

Objektif (nesnel) ve subjektif (öznel) olmak üzere iki tür sağlık-hastalık ölçümü vardır ve analizlere geçmeden önce aşağıda bu iki kavram üzerinde durulmaktadır.

\section{SAĞLIĞIN ÖLÇÜLMESİ: OBJEKTIFF VE SUBJEKTİF SAĞLIK ÖLÇÜMLERİ}

Sağl1k-hastalık ölçümleri objektif ve subjektif olmak üzere ikiye ayrılmaktadır. Objektif ölçümler fertlerin kendi öznel algıları, düşünceleri ve ruh hallerinden bağımsızdır ve tıbbi muayenelerden (kan testi vb.) elde edilir. Subjektif ölçümler ise fertlerin kendi bireysel görüşlerini yansıtır. Objektif ölçümler tıbbi muayenelerden subjektif ölçümler ise anketlerden elde edilir ve genellikle sağlıkla ilgili endişeleri içerir (“Sağl1k durumunuz nasıl, kronik müzmin bir hastalığınız var mı?” vb. (Romaniuk, 2014; Matrai, 2015; Bolsoy ve Sevil, 2006). Ancak, objektif ve subjektif ölçümler aynı şey değildir ve sağlık araştırmalarında bu iki ölçüm birbirinin yerine kullanılmamaktadır.

Bazı araştırmalar objektif ölçümlerin daha güvenilir olduğunu savunurken, diğerleri objektif ve subjektif ölçümler arasında tutarlılık ve yüksek bir korelâsyonun varlığından bahsetmekte ve diğer bazı araştırmalar da bu iki ölçüm arasındaki ilişkinin karmaşık olduğunu ileri sürmektedir (World Health Organisation, 2008; Wu, Wang, Zhao, 2013) Belirtildiği gibi toplumsal ve kültürel farklılıklar gösteren hastalık ister subjektif 
ister objektif anlamda olsun bireysel, mental, fiziksel, fizyolojik ve toplumsal düzeyde dengesizliği ifade etmektedir (Blaxter, 2004; Bolsoy ve Sevil, 2006).

Subjektif göstergelerin güvenilirliğini sorgulayan araştırmacılar sağlık durumlarının rapor edilmesinde dil, kavrayış, anlayış ve kültürel boyutta büyük farklılıkların olduğunu ifade etmektedirler. Çünkü "sağlıklı olma hali” kişiden kişiye değişiklik göstermekte ve soruların bağlamı kültürden kültüre farklılık arz etmektedir. Örneğin, "kronik bir hastalığınız var mı?” sorusuna "yok” yanıtı veren bir kişi tıbbi muayene neticesinde hipertansiyon vs. olabilir (Romaniuk, 2014). Ayrıca, bireylerin kendi algıladıkları subjektiföznel sağlık durumları ile yaşam koşulları arasındaki bağlantıya dikkat çekmek sağlık sosyolojisi için de önemlidir.

Subjektif göstergeler ülkelerin karşılaştırılmasında da karışıklıklara yol açmaktadır. Dil bağlamında soruların sorulma tarzı ülkeden ülkeye değişiklik göstermekte ve karşılaştırılabilir olmaktan uzaklaşmaktadır. Her ülkede aynı soruların aynı anlam ve bağlamda sorulması zordur çünkü cevaplar bir kültürden diğerine değişebilmektedir. Dil konusu kritik önemdedir çünkü soru cümlesini her ülkede aynı anlamda formüle etmek kolay değildir. Tercüme yapılırken anlam kaymaları vs. olması muhtemeldir. Dolayısı ile dil, kültür ve algı farklılıkları karşılaştırma yapmayı zorlaştırmaktadır (Romaniuk, 2014).

Subjektif ölçümler objektif ölçümlere nazaran daha pratik ve ucuzdur; fakat her iki ölçüm de önemlidir. Hangi ölçümün seçileceği araştırmanın bağlamına göre değişmektedir ve insanların kendilerini nasıl hissettikleri sağlık ölçümlerinde önemlidir. Objektif ölçümlerin de kendi içinde sınırlılıkları vardır; çünkü psikolojik rahatsızlıkları veya kronik ağrıları objektif olarak ölçmek çok zordur. Örneğin, Dünya Sağlık Örgütü (2008) anlaşılamayan (noncommuniciable cohronic desease) kronik hastalıkların yaygınlaştığına dikkat çekmektedir. Bütün bunlara ilaveten neyin objektif neyin subjektif olduğu ayrımını net bir şekilde yapmak da kolay değildir. Bazı subjektif durumlar objektif olarak ölçülebilirken bunun aksi de söz konusu 
olabilmektedir. Ağrı gibi subjektif bir kavramı objektif olarak ölçmek oldukça zordur. Dolayısı ile objektif subjektif ayrımı da göründüğü kadar net değildir (Romaniuk, 2014; Gataulinas ve Bancevica, 2014 ).

\section{YÖNTEM VE DEĞISSKENLER}

Avrupa Birliği’ne uyum sürecinde EUROSTAT (Avrupa Topluluğu İstatistik Ofisi) tüm üye ve üyelik müzakeresinde bulunan ülkelerde 2006 yılından itibaren Gelir ve Yaşam Koşulları (GYK) (Income and Living Conditions (EU-SILC) anketleri yapmaktadır. Bu anketlerin amac1 her yıl hem kesitsel hem de panel olarak üye ülkelerde gelir dağılımı ve sosyal dışlanmanın boyutlarını tespit etmektir. GYK anketleri ülkelerdeki gelir dağılımına, yoksulluğun düzeyi ve kompozisyonuna, yaşam koşullarına ve sosyal dışlanmaya dair bilgilerin derlenmesinde önemli bir kaynak olma niteliği taşımaktadır. Bu anketlerden gelir dağılımının yıllara göre seyri, zengin ve yoksul kesim arasındaki farklar, yoksunluk, sosyal dışlanma ve yaşam koşulları ile ilgili bilgiler elde edilmektedir (TÜİK, 2012).

Anketlerde sağlıkla ilgili yoksunluk boyutunu tespit etmek amacı ile hane halklarına genel sağlık durumları, kronik hastalıklarının olup olmadığı ve herhangi bir hastalık nedeni ile son altı ayda günlük faaliyetlerinde aksama olup olmadığı gibi değişkenler yer almaktadır. Aynı anket tüm değişkenleri ile Türkçeye tercüme edilerek 2006 yılından itibaren uygulanmaya başlanmıştır. Ayrıca, Ekonomik İşbirliği ve Kalkınma Örgütü (OECD) de "daha iyi yaşam endeksi" (beter life index) kapsamında sağlık durumu ile ilgili subjektif sağlık algılarını "daha iyi yaşam endeksi” kapsamında değerlendirmektedir.

Bu çalışmanın Türkiye ile ilgili verileri, TÜİK'in 2006-2012 yılları arasında yaptığ mikro verileri SPSS programında birleştirilerek subjektif algılara dayalı sağlık durumu, kronik hastalıklar ve günlük faaliyetlerde sınırlama değişkenleri kır-kent, cinsiyet, medeni durum, gelir ve eğitim düzeyine göre nasıl bir dağılım arz ettiği tanımlayıcı istatistik (çapraz tablolar ve ki-kare) teknikleri ile tahlil edilerek özetlenmiştir. OECD ve EUROSTAT'a ait istatistikler ise ilgili kurumların resmi web sayfalarından yüzdelik tablolar halinde derlenmiştir. 
TÜİK her yıl değişen ortalama 12-15 bin hane ile Türkiye genelinde ve kır kent olmak üzere kesitsel olarak bu anketleri yapmaktadır ve ulaşılan hanelerdeki her ferde sağlık durumu sorulmaktadır. Bu makalede sağlık durumu verilerini yanıtlayan hane halkı sayısı 2006'dan 2012 yılına kadar sırası ile 30 bin 186, 30 bin 263, 31 bin 141, 32 bin 539, 32 bin 875, 40 bin 679 ve 47 bin 504 olmak üzere 7 y1llik bir zaman diliminde toplamda 245 bin 187 kişiyi kapsamaktadır. Toplam 245,187 hane halkı ferdinin 117 bin 703 'ü erkek, 127 bin 484'ü kadın ve bu kişilerin 92 bin 518'i kır ve 152 bin 669'u da kentlerde ikamet etmektedir (TÜIKK, 2013).

Bu çalışmada üç değişken incelenip mukayese edilmiştir. İlk değişkende "sağlık durumunuz nasıl" sorusu sorulmakta ve yanıtlar Likert formatında "çok iyì", "iyi", "fena değil”, "kötü" ve "çok kötü" olmak üzere beş şıktan ibarettir. İkinci değişkende "kronik/müzmin bir hastalığınız var mı" ifadesi sorulmakta ve yanıtlar "evet", "hayır" şeklindedir. Üçüncü değişken ise herhangi bir sağlık sorunu nedeni ile son altı ayda günlük faaliyetlerde sınırlama olup olmadı̆̆ını sorgulamakta ve yanıtlar "evet, çok sınırlandı”, "evet, sınırlandı" ve "hayır, sınırlanmadı" şıklarını kapsamaktadır. Bu üç değişken EUROSTAT tarafindan “Avrupa Asgari Sağglı Modülü” (Minumum European Health Modul, MEHM” olarak adlandırılmaktadır. Dolayısı ile bu modül asgari düzeyde fertlerin kendi algılarına dayalı sağlık durumlarını ölçmektedir. Analiz sonuçları aşağıda tablolar halinde özetlenmektedir.

\section{BULGULAR: SAĞLIK DURUMU, OECD VE DAHA İYİ YAŞAM ENDEKSİ}

TÜİK ve EUROSTAT'ın araştırmalarından bağımsız olarak OECD her yıl “daha iyi yaşam endeksi” kapsamında üye ülkelerde sağlık durumu göstergeleri yayınlamaktadır. OECD’nin 2017 yılına ait paylaştığ1 göstergeler Türkiye ile nüfus ve büyüklük bakımından mukayese edilebilir ülkeler seçilerek Tablo 1'de sunulmuştur. OECD "sağlık durumunuz nasıl" sorusunda "çok iyi" ve "iyi” seçeneklerini birleştirerek yayınlamaktadır. Birinci sütundaki sağlık durumu subjektif ölçüm ve ikinci sütundaki ortalama yaşam süresi de objektif sağl1k ölçümüdür.

$\mathrm{SAD} / \mathrm{JSR}$

Cilt / Volume 22 Sayı / Number 1 
Tablo 1. OECD Ülkeleri ve Sağlık Durumu, 2017

\begin{tabular}{|l|c|c|}
\hline & Sağlık durumu çok iyi + iyi \% & Ortalama yaşam süresi \\
\hline Türkiye & 66.4 & 78 \\
\hline Almanya & 64.5 & 80.7 \\
\hline A.B.D. & 88.1 & 78.8 \\
\hline Brezilya & 69.6 & 74.7 \\
\hline Fransa & 67.8 & 82.6 \\
\hline Güney Kore & 32.5 & 82.1 \\
\hline İngiltere & 69.8 & 81 \\
\hline İsrail & 84 & 82 \\
\hline İspanya & 72.4 & 83 \\
\hline Japonya & 35.4 & 75.9 \\
\hline Meksika & 65.5 & 77.6 \\
\hline Polonya & 57.8 & 71.3 \\
\hline Rusya & 43 & 79.1 \\
\hline Şili & 57.4 & \\
\hline
\end{tabular}

http://www.oecdbetterlifeindex.org/topics/health/

Tablo1'de sağlık durumu “çok iyi” artı "iyi” toplamı Türkiye, Almanya, Fransa, İngiltere ve Brezilya gibi ülkelerde \%65-\%70 arasında birbirine yakındır.

Öte yandan Güney Kore ve Japonya'da aksi bir durum söz konusudur ve bu ülkelerde nüfusun yaklaşık \%65 ile \%70’i sağlık durumlarının “iyi” olmadığını rapor etmektedirler ve buna rağmen ortalama ömür bu ülkelerde 83 yaş civarındadır. Bu ülkeler farklı coğrafi kültür ve yaşam ritimleri ile Avrupa ülkelerinden ayrı bir görüntü sunmaktadırlar.

Subjektif ve objektif sağlık ölçümlerinde zıtlık arz eden diğer iki ülke Amerika ve Rusya'dır. ABD'de sağlık durumu “iyi” artı “çok iyi” \%88 ile üst sıralardayken ortalama ömür (78 yaş) Türkiye ile aynıdır. Rusya'da nüfusun \%60'a yakını sağlık durumunun iyi olmadığını ifade ederken ortalama ömür 71 yaştır. 
İsrail ortalama \%84 ile en sağlıklı birkaç ülkeden biri olarak yer almaktadır. Ancak, Levi (2017) İsrail'de ölçümün farklı yapıldığı için sonuçların yüksek çıktığını belirtmektedir.

Çünkü sağlık durumunuz nasıl sorusunun cevap şıkları diğer tüm ülkelerde "çok iyi”den çok kötüye beş seçenek içerirken İsrail'de sadece dört seçenek sorularak ortaya denk gelen "fena değil" yanıtı yer almamakta ve iki pozitif ve iki negatif seçenek olduğu için pozitif yanıtlar daha fazla oranda çıkmaktadır.

Özetle, OECD’nin sonuçlarına göre 34 üye ülkenin sağlık durumu "çok iyi” ve "iyi” ortalaması \%65 ile \%70 arasında yer almaktadır. Bir diğer ifade ile OECD'ye üye ülkelerde sağlık durumu "iyi değil" ortalamas $1 \% 30$ ile $\% 35$ civarındadır.

Tablo 2'de OECD’nin araştırmasından farklı olarak Türkiye'de 2006 ile 2012 yılları arasında yapılan GYK araştırmalarının sonuçları yıllar, kır-kent, medeni durum, gelir ve eğitim düzeyine göre çapraz tablolarda sunulmuştur.

Tablo 2. Ferdin Genel Sağlık Durumu: 2006-2012 GYK Araştırma Sonuçları: Yıl, Kır-Kent, Medeni Durum, Gelir ve Eğitim Düzeyi

\begin{tabular}{|l|l|l|l|l|l|}
\hline & Çok iyi (\%) & İyi (\%) & Fena değil (\%) & Kötü (\%) & Çok kötü (\%) \\
\hline $\mathbf{2 0 0 6}$ & 10.7 & 50.1 & 22.2 & 14.9 & 2.1 \\
\hline $\mathbf{2 0 0 7}$ & 13.4 & 51.2 & 19.9 & 13.4 & 2.2 \\
\hline $\mathbf{2 0 0 8}$ & 11.7 & 54.2 & 20.8 & 11.7 & 1.5 \\
\hline $\mathbf{2 0 0 9}$ & 11.7 & 51.6 & 21.5 & 12.8 & 2.3 \\
\hline $\mathbf{2 0 1 0}$ & 11 & 53.2 & 20.5 & 13.1 & 2.2 \\
\hline $\mathbf{2 0 1 1}$ & 12.2 & 52.7 & 20.7 & 12.2 & 2.2 \\
\hline $\mathbf{2 0 1 2}$ & 12.3 & 53.8 & 19.9 & 12.1 & 1.9 \\
\hline Kır & 11 & 47.7 & 21.9 & 16.6 & 2.8 \\
\hline Kent & 12.4 & 55.5 & 20 & 10.5 & 1.6 \\
\hline Erkek & 13.6 & 55.9 & 18.8 & 10 & 1.7 \\
\hline Kadın & 10.3 & 49.4 & 22.6 & 15.4 & 2.3 \\
\hline
\end{tabular}




\begin{tabular}{|l|l|l|l|l|l|}
\hline & Çok iyi (\%) & İyi (\%) & Fena değil (\%) & Kötü (\%) & Çok kötü (\%) \\
\hline Evli & 24.7 & 63.3 & 6.5 & 4.2 & 1.3 \\
\hline Hiç evlenmedi & 8.6 & 52.1 & 24.2 & 13.4 & 1.7 \\
\hline Eşi Öldü & 1 & 18.1 & 35.2 & 37.3 & 8.4 \\
\hline Ayrı yaşıyor & 4.2 & 32.9 & 30 & 27.7 & 5.1 \\
\hline $\mathbf{1 . 2 0}$ & 10,2 & 43,2 & 20,9 & 20,7 & 5,0 \\
\hline $\mathbf{2 . 2 0}$ & 10,1 & 47,3 & 23,4 & 16,3 & 2,8 \\
\hline $\mathbf{3 . 2 0}$ & 8,9 & 48,4 & 25,8 & 14,7 & 2,2 \\
\hline $\mathbf{4 . 2 0}$ & 10,1 & 57,3 & 22,7 & 9,0 & 1,0 \\
\hline $\mathbf{5 . 2 0}$ & 13,8 & 63,3 & 17,9 & 4,7 & 0,4 \\
\hline İlkokuldan az & 4,9 & 31,5 & 28,1 & 29,6 & 5,9 \\
\hline İlk\&ortaöğretim & 11,8 & 55,4 & 21,5 & 10,1 & 1,2 \\
\hline Lise ve dengi & 18,2 & 64,9 & 12,7 & 3,7 &, 4 \\
\hline Üniversite ve + & 18,9 & 66,3 & 11,8 & 2,7 &, 3 \\
\hline Toplam & 11.9 & 52.5 & 20.7 & 12.8 & 2 \\
\hline
\end{tabular}

Gelir ve Yaşam Koşulları, TÜİK, 2006-2012

TÜİK'in 2006-2012 verileri ile OECD'nin 2017 yılındaki bulguları birbirine çok yakındır. OECD’nin, 2017 yılı sağlık durumu (çok iyi+iyi) araştırma sonucu \%66,4; TÜİK’in 2006-2012 arasında yaptığı GYK ortalaması ise \%64,8' dir. Bu makalede incelenen veriler 2012 yılına kadar olduğu için ilk bakışta eski gibi gözükebilir. Fakat halk sağlı̆̆ ile ilgili temel parametreler 10-15 yıllık bir zaman diliminde çok hızlı değişmemektedir. Örneğin, Türkiye'de 2006-2012 yılları arasında ortalama olarak nüfusun \%65'i “iyi” ve “çok iyi” olduğunu rapor etmiştir. Bu oranlar 2020’li yıllarda da aşağı yukarı benzer olacaktır. Avrupa Birliği ülkelerinde Avrupa Asgari Sağlık Modülü kapsamında uzun yıllardır uygulanmaktadır ve EOROSTAT sayfaları incelendiğinde yıllar itibarı ile bulguların çok fazla değişmediği görülmektedir.

Türkiye açısından ortalamalar kır-kent, cinsiyet, medeni durum, gelir ve eğitim düzeyine göre çapraz tablolarla özetlendiğinde kırsal bölgelerde 2006 ve 2012 yılları arasında “çok iyi” ve "iyi” ortalaması toplam \%58,7 iken bu oran kentlerde $\% 67,9$ 'dur. Kır ve kent arasındaki fark yüksek olmamakla birlikte kırsal bölgelerdeki yaşam şartları, gelirin daha düşük olması ve sağlı hizmetlerine erişimin kısıtlı olması 
dolayısı ile tüm dünyada olduğu gibi Türkiye'de de kırsal bölgelerde sağlık durumu algıları kentlere göre biraz daha düşüktür. "Kötü” ve “çok kötü” oranının toplamı kırsal yerleşimlerde \%19,4, kentlerde ise $\% 12$ 'dir.

Sağlık ve hastalık algılarında bir diğer önemli faktör medeni durumdur. Ki-kare testi sonuçlarına göre $(\chi 2=$ 34798,9, df=16, $\mathrm{P}=0.001$ ) Türkiye'de medeni durum ve sağlık durumu arasında güçlü bir ilişki vardır. Bireylerin evli, bekâr, dul veya boşanmış olması sağlık algılarını etkilemektedir. Sonuçlara göre evlilerin \%88'i sağl1k durumunun "iyi” ve "çok iyi” olduğunu belirtirken bu oran hiç evlenmeyenlerde \%60,7, eşi ölenlerde \%19,1 ve ayrı yaşayanlarda ise \%37,1'dir. Dolayısı ile Türkiye bağlamında sosyo-ekonomik ve demografik değişkenler bakımından en büyük farklardan biri medeni durumda ortaya çıkmaktadır. Nitekim evliliğin getirdiği sosyal kontrol, risklerden kaçınma, sorumluluk ve diğer düzenlemeler sağlıklı yaşamı da beraberinde getirmektedir. Evliler daha çok sosyal destek bulmaktadır ve düzenli yaşam tarzına sahiptir. Dolayısı ile hastalıklara yakalanma riskleri daha azdır ve hastalıklara yakalandıklarında da daha çabuk iyileşmektedirler (Alptekin, 2018). Tabloda ortaya çıkan sonuç Türkiye bakımından bu görüşü desteklemektedir.

Bir diğer etken ise evli olmayan kişilerin evli olanlara nazaran daha düşük sosyo-ekonomik statüde olmaları nedeni ile hastalıklara yakalanma riskleri ve sağlık harcamalarını karşılayabilmeleri sağlık algılarını etkilemektedir. Bekâr ve boşanmış kadınların hastalığa yakalanma yatkınlıkları daha fazladır. Çünkü evlilere göre ekonomik durumları daha düşüktür, sosyal destek daha az ve özetle evli bireyler bekâr, dul ve boşanmış bireylere göre daha sağlıklı olmaktadır. Bazı uluslararası çalışmalarda benzer bulgular ortaya çıkmıştır fakat diğerlerinde ise evli bireylerin olumlu yönde cevaplar verdikleri ve objektif sağlık ölçümlerinde farkların çok fazla olmadığı ifade edilmiştir (Hui, Z. vd., 2013; Kaisla ve diğ, 2006)

Ki-kare testi sonuçlarına göre ( $\chi 2: 7589$, df:20, P:0.001) gelir düzeyi ile sağlık durumu arasında ilişki vardır ve gelir düzeyi yükseldikçe sağlık durumu açısından iyi olma hali anlamlı bir artış eğilimi göstermektedir. 
Tablo 1'de en alt \%20'den en üst \%20'ye kadar sağl1k durumu "çok iyi” ve "iyi”" ortalama \%10 ile aynı orandayken iyi olduğunu beyan edenlerin oranı ise gelir düzeyi yükseldikçe en alt dilimden en üst dilime \%43, \%47, \%48, \%57 ve \%63 ile düzenli bir artış eğilimindedir. İlk üç gelir dilimi aynı yelpazede yer alırken en yüksek 4. \%20 ve 5. \%20 dilimleri ise kendi arasında benzerlik arz etmektedir. "Fena değil" seçeneği de olumlu değerlendirilirse ortalamalar sırası ile $\% 74, \% 81, \% 83, \% 90$ ve $\% 95$ değerlerini göstermektedir. Ancak, her değişken birbirinden bağımsız ele alındığında pozitif sağlık algılarında derece bakımından medeni durum ve eğitim düzeyi gelir düzeyine göre daha güçlüdür. Gelir düzeyi bireylerin sağl1k ve hastalık durumunu doğrudan etkilemektedir. Diğer ülkelerde de olduğu gibi gelir düzeylerinin artmasına paralel olarak sağlıklı olmak daha mümkün hale gelmektedir. Gelir düzeyi yüksek olan bireyler sağlı hizmetlerine daha rahat ulaşmakta ve aldıkları sağlık hizmetlerinin kalitesi de yüksek olabilmektedir.

Analize tabi tutulan bir diğer önemli faktör eğitim düzeyidir. Çünkü eğitim düzeyi yükseldikçe sağlıklı olma bilinci ve sağlıklı bir yaşam tarzına sahip olma imkânı artmaktadır. Tablo 1'de eğitim düzeyi ve sağlık durumu arasında Ki-Kare değerinin de işaret ettiği üzere $(\chi 2=36922,9, \mathrm{df}=12, \mathrm{P}=0.001)$ çok güçlü bir ilişki vardır. İlkokuldan daha düşük eğitim düzeyindeki bireylerin \%36'sı sağlık durumunun “çok iyi” ve “iyi” olduğunu beyan ederken bu oranlar ilkokul ve ilköğretim mezunlarında $\% 67,2$, lise ve denginde $\% 83,1$ ve üniversite ve üzeri mezunlarında \%85,2'dir. Sağlık durumu algılarında en büyük fark gelir, cinsiyet, kırkent değişkenlerinden ziyade medeni durum, eğitim düzeyi ve gelir seviyesinde kendini göstermektedir. Dünyanın her yerinde olduğu gibi Türkiye' de de eğitim düzeyi yüksek bireyler düşük olanlara nispetle daha iyi gelir getiren yüksek standartlı mesleklerde çalışmaktadırlar. Hastalıklara yakalanma riskleri düşük eğitim düzeyindeki bireylere kıyasla daha azdır. Bu bağlamda, eğitimli kişiler sağlık konusunda daha bilinçlidir, daha çok egzersiz ve spor yapmaya eğilimlidir, sağlıklı beslenme imkânları daha fazladır ve düzenli ve dengeli beslenme konusunda daha bilinçlidirler. 


\section{CINSIYYET VE SAĞLIK: AB ÜLKELERİ VE TÜRKIYYE}

Sağlık algılarında bir diğer önemli faktörün biyolojik farklılığa dayalı cinsiyet olduğu ifade edilmektedir. Gelişmişlik derecesi ne olursa olsun bütün ülkelerde istatistikler kadınların erkeklere nispetle ortalama 5-7 yıl daha fazla yaşadıklarını ortaya koymaktadır. Fakat bu kadınların erkeklerden daha sağlıklı olduğu anlamına gelmemektedir. Araştırmalar genelde tüm dünyada daha erken ölen erkeklerin daha uzun yaşayan kadınlar kadar hastalık tecrübesi yaşamadıklarını göstermektedir (Alptekin, 2018).

Tablo 3'te EOROSTAT'ın 2016 yılı verileri kadın ve erkeklerde sağlık durumu dağılımını göstermektedir. Ayrıca, Türkiye ile Avrupa Birliği ülkeleri mukayesesinde Türkiye’ye ait veriler 2006 ve 2012 yıllarını kapsarken EOROSTAT verileri 2008 ve 2016 yıllarını kapsamaktadır. Sağl1k durumu gibi temel göstergeler 4-5 y1llık dönemlerde çok fazla değişiklik göstermemektedir. Tablo 1'de OECD’nin 2016 verileri ile GYK verilerinin 2006-2012 dağılımı ve aynı zamanda Tablo 4'te 2010-2012 Avrupa Birliği ve Türkiye ortalamaları da bunu desteklemektedir. Türkiye verileri ile OECD arasında bir diğer fark da yaş faktörüdür. Aşağıda özetlenen tüm EUROSTAT verileri 16 yaş ve üzeri kişilerle sınırlı iken TÜİK'in GYK verilerine tüm yaş grupları dâhildir.

2016 yılında EOROSTAT'ın Tablo 3'te özetlenen verilerine göre 16 yaş ve üzeri bireylerde sağlık algılarının ortalama dağılımı sağlık durumu "iyi” ve "çok iyi” toplamı erkeklerde \%70 kadınlarda ise \%65,1'dir. "Kötü” ve “çok kötü” ortalaması ise erkeklerde \%9,7 ve kadınlarda \%9,9'dur. Türkiye ortalaması ise 2006 ve 2012 yılları arasında “iyi” ve “çok iyi” erkeklerde \%69,5 kadınlarda \%59,7'dir. “Kötü” ve “çok kötü” ortalamaları Avrupa Birliği’nde erkeklerde \%7,7, kadınlarda 9,9'dur. “Kötü” ve “çok kötü’ ortalamaları Türkiye'de erkeklerde $\% 11,7$ ve kadınlarda \%14,9'dur. 
Tablo 3. Avrupa Birliği (28 üye) Ülkelerinde Cinsiyet ve Sağlık Durumu, 2016 (EUROSTAT) Türkiye'de Cinsiyet ve Sağlık Durumu: 2006-2012 (TüIK)

\begin{tabular}{|l|c|c|c|c|c|c|}
\hline & \multicolumn{3}{|c|}{ Erkek } & \multicolumn{3}{c|}{ Kadın } \\
\hline AB -28 ülke & $\begin{array}{c}\text { İyi }+ \\
\text { Orok iyi }\end{array}$ & $\begin{array}{c}\text { Fena } \\
\text { değil }\end{array}$ & $\begin{array}{c}\text { Kötü + } \\
\text { çok kötüi }\end{array}$ & $\begin{array}{c}\text { Iyyi + } \\
\text { çok iyi }\end{array}$ & $\begin{array}{c}\text { Fena } \\
\text { değil }\end{array}$ & $\begin{array}{c}\text { Kötü + } \\
\text { çok kötü }\end{array}$ \\
\hline AB 28 ülke & 70.1 & 22.2 & 7.7 & 65.1 & 25 & 9.9 \\
\hline Türkiye & 69.5 & 18.8 & 11.7 & 59.7 & 25.4 & 14.9 \\
\hline Almanya & 66.8 & 25.1 & 8 & 63.6 & 27.8 & 8.6 \\
\hline Fransa & 68.3 & 24.5 & 7.2 & 64.7 & 26.4 & 8.9 \\
\hline Polonya & 62 & 25.8 & 12.2 & 55.6 & 29.5 & 14.8 \\
\hline Portekiz & 52.6 & 34.8 & 12.7 & 43.3 & 37.9 & 18.8 \\
\hline
\end{tabular}

https://ec.europa.eu/eurostat/statisticsexplained/images/e/e5/Distribution_of_persons_aged_16_and_over_ by self-perceived health status\%2C by sex\%2C $2016 \% 28 \% 25 \% 29$ Health2017.png

Kadın ve erkeklerin sağlığına dair dünya genelinde farklılıklar hemen her ülkede görülmektedir. Tablo 3 'te de görüldüğü gibi Türkiye, erkeklerin pozitif sağlık algılarında Almanya ve Fransa'nın birkaç puan üzerindeyken, Almanya'da kadınların \%63,6's1, Fransa'da \%64,7'si, Türkiye'de 59,7'si, Polonya'da \%55,6's1 ve Portekiz'de ise \%43,3'ü sağlık durumlarının iyi olduğunu ifade etmektedirler. 28 üyeli Avrupa Birliği’nde 2016 yılında kadınların \%65,1'i Türkiye’de ise 2006-2012 yılları arasında tüm yaş grupları dâhil olmak üzere kadınların ortalaması \%60’tır. Dolayısı ile Avrupa Birliği ülkeleri ile Türkiye arasında cinsiyet açısından sağlık durumunda anlamlı bir fark bulunmamaktadır. Türkiye'de sağlık durumunda cinsiyet faktörü tek başına açıklayıcı değildir ve cinsiyetten çok daha önemli medeni durum, gelir ve eğitim düzeyi etkili olmaktadır.

\section{KRONIKK HASTALIKLAR VE SAĞLIK ALGILARI}

Analize tabi tutulan ikinci değişken fertlerin kronik/müzmin bir hastalığının olup olmadığını sorgulamaktadır. Kronik/müzmin hastalıklar şeker, kanser, hipertansiyon, kalp-damar hastalıkları, astım, böbrek yetmezliği, romatizmalı hastalıklar, $\mathrm{KOAH}$, mide-bağırsak hastalıkları, nörolojik hastalıklar, cilt hastalıkları, kas hastalıkları, psikolojik hastalıklar, kadın hastalıkları gibi günümüzde tüm toplumları 
etkileyen ve bulaşıcı olmayan kronik hastalıkları kapsamaktadır (Sağlık Bakanlığı, 2018). Tablo 4 ve 5 'te EOROSTAT'ın GYK araştırmalarının sonuçları ve Tablo 6' da TÜİK'in yaptığı GYK araştırma sonuçları özetlenmektedir.

Tablo 4. Avrupa Birliği Ülkeleri Kronik Hastalıklar: 2010-2016 (\%) Türkiye’de Kronik Hastalıklar: 2006-2012 (\%)

\begin{tabular}{|l|l|}
\hline 2010 AB ülkeleri & 30.9 \\
\hline 2011 AB ülkeleri & 31.2 \\
\hline 2012 AB ülkeleri & 30.8 \\
\hline 2013 AB ülkeleri & 31.8 \\
\hline 2014 AB ülkeleri & 32.3 \\
\hline 2015 AB ülkeleri & 34.1 \\
\hline 2016 AB ülkeleri & 32.9 \\
\hline 2010 Türkiye & 31.5 \\
\hline 2011 Türkiye & 32 \\
\hline 2012 Türkiye & 31.6 \\
\hline 2006-2012 GYK Türkiye Ortalaması & 30.9 \\
\hline
\end{tabular}

http://appsso.eurostat.ec.europa.eu/nui/show.do?dataset=hlth_silc_05\&lang=en

Tablo 4'de EUROSTAT'ın yaptığı GYK araştırma sonuçları 2010 yılından 2016'ya kadar yedi yıllık bir süreçte Avrupa Birliğine üye ülkelerde kronik hastalığı olduğunu rapor edenlerin ortalama oranı \%32'dir ve Türkiye' de ise 2006-2012 sonuçlarına göre kronik hasta oranı \%30,9'dur. Tablo 6'da GYK sonuçları ve Tablo 4'te AB ülke sonuçlarına göre kronik hastalıkların genel ortalama oranı Türkiye'de 2010'da \%31,5, 2011 'de $\% 32,2012$ 'de $\% 31,6$; AB ülkelerinde ise aynı y1llarda ortalamalar \%30,9, \%31,2 ve \%30,8 ile aynı orandadır. 
Tablo 5. 13 AB Üyesi Ülke ve Türkiye'de Kronik Hastalıkların Oranı: 2008

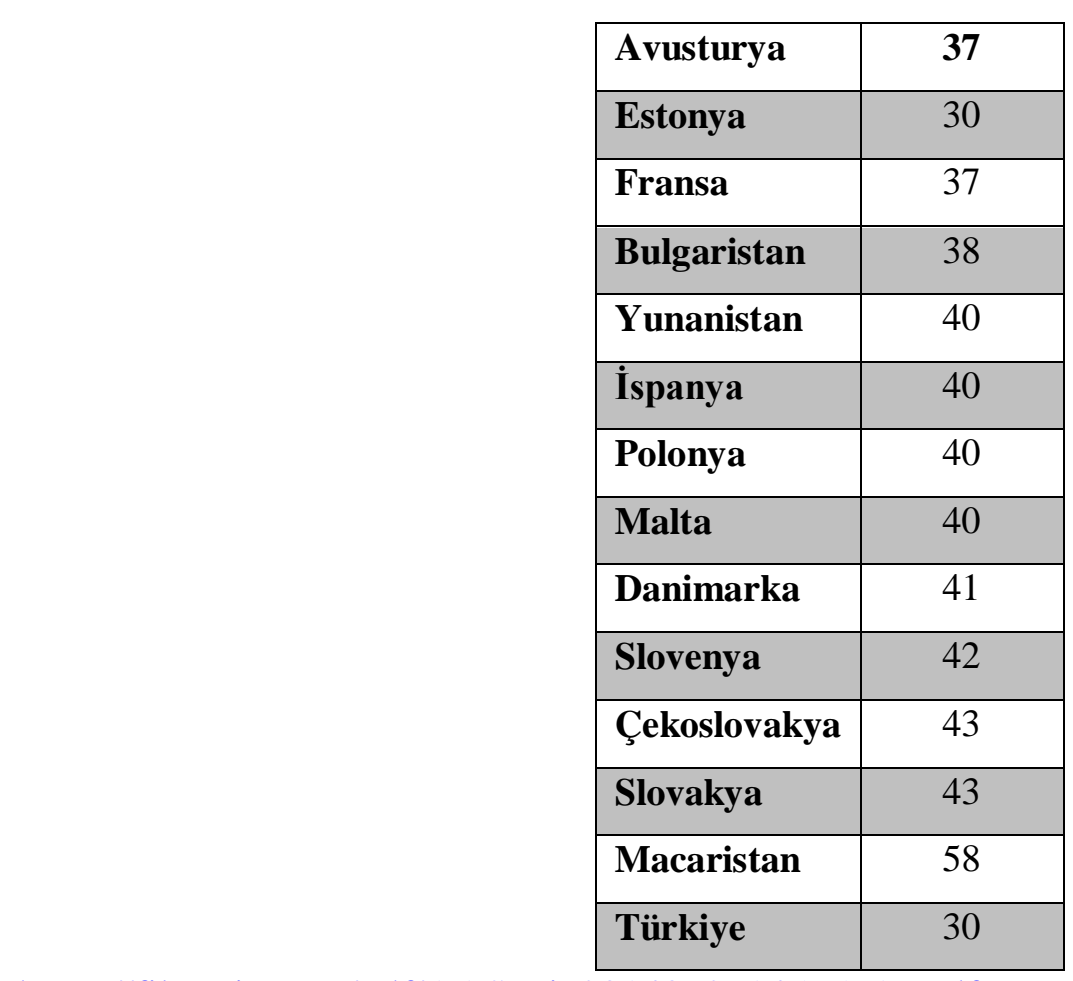

https://file.scirp.org/pdf/AASoci_2014092614575716.pdf

Gataulinas ve Bancevica (2014) AB ülkelerinin ortalamasından farklı olarak 2008 y1lına ait kronik hastalıkların 13 üye ülkedeki dağılımları inceledikleri makalelerindeki sonuçlar Tablo 5'te sunulmaktadır. 2008 yılında ortalamaların üstünde yer alan 13 AB ülkesinde nüfusun \%40’1 bir veya daha fazla kronik hastalığının olduğunu rapor etmiştir. Türkiye'de ise aynı yıl itibarı ile kronik hastalığı olduğunu rapor edenler \%30’dur. Özellikle, Slovakya, Çekoslovakya, Danimarka, Slovenya, Yunanistan, İspanya, Polonya ve Macaristan gibi ülkelerde genel nüfus içinde kronik hastalıkların oranı $\% 40$ ve üzerindedir.

Tablo 6'da 2006-2012 yılları arasında ve yedi yıllık bir süreçte Türkiye'de GYK anketleri sonuçlarına göre kronik hastalığı olduğunu rapor edenlerin ortalama oranı toplamda \%30'dur ve bu oranlar kır-kent, kadınerkek, medeni durum, gelir ve eğitim düzeyine göre detaylandırıldığında ortaya çıkan sonuçlar aşağıda özetlenmektedir. 
Tablo 6. Ferdin Kronik Bir Hastalığının Olup Olmadığı: 2006-2012 GYK Araştırma Sonuçları: Yıl, Kır-Kent, Medeni Durum, Gelir ve Eğitim Düzeyi, Türkiye

\begin{tabular}{|l|c|c|}
\hline & Evet (\%) & Hayır (\%) \\
\hline $\mathbf{2 0 0 6}$ & 30.5 & 69.5 \\
\hline $\mathbf{2 0 0 7}$ & 29 & 71 \\
\hline $\mathbf{2 0 0 8}$ & 29.7 & 70.3 \\
\hline $\mathbf{2 0 0 9}$ & 31.8 & 68.2 \\
\hline $\mathbf{2 0 1 0}$ & 31.5 & 68.5 \\
\hline $\mathbf{2 0 1 1}$ & 32 & 68 \\
\hline $\mathbf{2 0 1 2}$ & 31.6 & 68.4 \\
\hline Kır & 34.9 & 65.1 \\
\hline Kent & 28.6 & 71.4 \\
\hline Erkek & 26.2 & 73.8 \\
\hline Kadın & 35.4 & 64.6 \\
\hline Evli & 9.2 & 90.8 \\
\hline Hiç evlenmedi & 34.5 & 65.5 \\
\hline Eşi Öldü & 74 & 26 \\
\hline Ayrı yaşıyor & 54.7 & 45.3 \\
\hline 1. 20 & 38,1 & 61,9 \\
\hline $\mathbf{2 . 2 0}$ & 34,7 & 65,3 \\
\hline 3. 20 & 37,7 & 62,3 \\
\hline $\mathbf{4 . 2 0}$ & 30,3 & 69,7 \\
\hline $\mathbf{5 . 2 0}$ & 24,0 & 76,0 \\
\hline İlkokuldan az & 54,0 & 46,0 \\
\hline İlk ve ortaöğretim & 28,1 & 71,9 \\
\hline Lise ve dengi & 15,6 & 84,4 \\
\hline Üniversite ve + & 17,3 & 82,7 \\
\hline Toplam & 31,0 & 69,0 \\
\hline
\end{tabular}

Anket Türkiye genelini kapsadığı için bu oran sayılara döküldüğünde Türkiye'de yaklaşık 24 milyon insanın kronik bir hastalığı olduğu ortaya çıkmaktadır. Nitekim 2014 yılında Sağlık Bakanlığı'nın bulgularına göre bu rakam 22 milyondur (\%27) ve bu anketin sonuçları da Sağlık Bakanlığı'nın verilerine $\mathrm{SAD} / \mathrm{JSR}$ 
yakındır. Sağlık Bakanlı̆̆ı'nın açıklamasına göre Türkiye'de sadece şeker hastası sayısı 7 milyondur ve ülkeye yıllık maliyeti 13 milyar doları bulmaktadır. Bu sonuçlara göre Türkiye'de her 3 kişiden birinde bir veya daha fazla kronik hastalık vardır ve tanı konulan hastaların her üç kişiden birinde depresyon belirtileri görülmüştür. (Sağlık Bakanlığı, 2008).

Tablo 6'da kadınların \%35,4'ü erkeklerin ise \%26,2'si kronik hastalığı olduğunu belirtirken, evlilerin \%9,2'si, hiç evlenmeyenlerin \%34,5'i eşi ölenlerin \%74'ü ve ayrı yaşayanların da \%54,7'si kronik bir hastalığının olduğunu bildirmiştir. Eşi ölenler ekseriyetle yaşlı kişiler olduğu için sonuç yüksek çıkmaktadır. En alt \%20’lik gelir diliminden en üst \%20'lik gelir dilimine doğru kronik hastalıkların oranı sırası ile $\% 38,1, \% 34,7, \% 37,7, \% 30,3$ ve $\% 24$ 'dür. En alt gelir dilimi ile en üst arasında \%14'lük bir fark olduğu görülmektedir.

İlkokuldan daha az eğitim düzeyindeki fertlerin $\% 54$ 'ü, ilk ve orta öğretimlilerin $\% 28,1$ 'i lise ve dengi $\% 15,6$ ve üniversite ve üzerinde rapor edilen kronik hastalık oranı \%17,3’tür.

Türkiye' de eğitim düzeyi ilkokuldan daha az olan ya da okuma yazması olmayan bireyler 60 yaş ve üzerindedir ve gelir diliminin de en alt \%20'lik bölümünde yer almaktadırlar. Bu bağlamda yaş, eğitim düzeyi, gelir ve medeni durumdaki eşin ölmesi kesişmekte ve kronik hastalıkların dağılımı da ortalamaların üzerinde bu kategorilerde yoğunlaşmaktadır.

Ancak Tablo 4 ve 5'te 28 üyeli AB ülkeleri ile karşılaştırıldığında toplumların yaklaşık \%30'nun kronik hastalığ1 olduğunu belirtmesi bu ülkelerde temelde insan sağlı̆̆ üzerinde benzer süreçlerin işlediğine işaret etmektedir. Amerika'da yapılan araştırmalarda sonuçlar daha yüksek çıkmakta ve her iki yetişkinden birinin bir veya birden fazla kronik bir hastalığının olduğu belirtilmektedir (Center for Disease Control and Prevention, 2018). Her toplum farklı sosyo-ekonomik ve kültürel koşullarda yaşadığına göre bu temel benzerlikler ancak insan vücudunun zamanla her yerde aynı süreçlerden geçtiğine işaret etmektedir.

$\mathrm{SAD} / \mathrm{JSR}$

Cilt / Volume 22 Sayı / Number 1 
Dünya Sağlık Örgütü ve Birleşmiş Milletler, kronik hastalıkları 21. yüzyılın en önemli sağlık sorunu olarak tanımlamaktadır. Gelir düzeyi ne kadar yüksek olursa olsun her yerde insanlar hastalanmaktadır ve kronik hastalıkların oranı pek çok ülkede birbirine yakındır. Dolayısı ile tedavi imkânları geniş ve eğitim düzeyinin yüksekliğinden dolayı insanlar daha bilinçli olduğu için kronik hasta olsalar bile bu hastalıkları uzun vadede kontrol altına alarak daha uzun yaşamaktadırlar. Örneğin, Fransa ve İspanya'da ortalama yaşam süresi 83 seneyken kronik hastalıkların oranı \%41'dir.

Avrupa Bölgesi'nde yaklaşık 60 milyon diyabetli hasta olduğu ve erkeklerin yaklaşık 10,3'ü kadınların ise 9,6'sının şeker hastası olduğu raporlara yansımaktadır. Diyabet ortalamaları yüksek gelirli ülkelerde ortalama $\% 8$, orta gelirli ülkelerde $\% 9$ ve düşük gelirli ülkelerde ise ortalama $\% 5$ ’tir. Türkiye’de kötü beslenme, kilo ve obezite ile günlük aktivite eksikliğinden dolayı Avrupa'da en hızlı artışın Türkiye'de olduğu ifade edilmektedir (Sağlık Bakanlığı, 2018).

Tıp dünyası kronik-müzmin hastalıkların önlenebilir olduğunu iddia etmektedir fakat tanımı gereği kronik hastalık tedavi edilemeyen ve devamlı nükseden hastalık demektir. Bu hastalıklar ilaçlarla kontrol altında tutulmaktadır ve hastalık hiçbir zaman tamamen iyileşmemektedir. Ancak, sağlıssız beslenme, tütün kullanımı, yetersiz hareket ve obezite kronik hastalıkların kontrolünde önde gelen risk faktörleri arasındadır. 


\section{SAĞLIK SORUNU VE GÜNLÜK FALİYETLERDE SINIRLANMA}

Tablo 7. Sağlık Sorunu Nedeni ile Son 6 Ayda Günlük Faaliyetlerde Sınırlama: Avrupa Birliği Ülkeleri (2015) ve Türkiye (2006-2012)

\begin{tabular}{|c|c|c|c|}
\hline AB 28 Üye (2015) & Evet, çok sınırlandı \% & Evet, sınırlandı \% & Hayır sınırlanmadı \% \\
\hline AB 28 Üye (2015) & 7.5 & 17.3 & 75.2 \\
\hline Türkiye-2006-2012 & 8.6 & 20.1 & 71.6 \\
\hline Belçika & 9.2 & 15.7 & 75.1 \\
\hline Bulgaristan & 3.7 & 12.5 & 83.8 \\
\hline Çekya & 6 & 19.3 & 74.8 \\
\hline Danimarka & 6.1 & 22.5 & 71.3 \\
\hline Almanya & 7.2 & 14.1 & 78.7 \\
\hline Estonya & 8.9 & 23.5 & 67.7 \\
\hline İrlanda & 5.3 & 12.4 & 82.2 \\
\hline Yunanistan & 11.2 & 13.5 & 75.3 \\
\hline İspanya & 4.6 & 18.1 & 77.4 \\
\hline Fransa & 8.9 & 16.8 & 74.3 \\
\hline Hurvatistan & 9.6 & 22.6 & 67.7 \\
\hline İtalya & 6.1 & 16.2 & 77.5 \\
\hline Kibris Rum & 5.1 & 10.9 & 84 \\
\hline Latviya & 8.6 & 28.7 & 62.6 \\
\hline Litvanya & 6.3 & 23 & 70.7 \\
\hline Lüksemburg & 9 & 16.7 & 74.3 \\
\hline Macaristan & 7 & 19.8 & 73.2 \\
\hline Malta & 3.5 & 9.4 & 87.1 \\
\hline Hollanda & 6.1 & 23.5 & 70.5 \\
\hline Avusturya & 9.1 & 25.1 & 65.8 \\
\hline Polonya & 7 & 15.8 & 77.2 \\
\hline Portekiz & 8.2 & 24.8 & 67 \\
\hline Romanya & 6 & 20.1 & 73.9 \\
\hline Slovenya & 8.6 & 22.7 & 68.8 \\
\hline Slovakya & 8.4 & 21 & 70.6 \\
\hline
\end{tabular}




\begin{tabular}{|l|c|c|c|}
\hline AB 28 Üye (2015) & Evet, çok sınırlandı \% & Evet, sınırlandı \% & Hayır sınırlanmadı \% \\
\hline Finlandiya & 7.6 & 25 & 67.4 \\
\hline İsveç & 3.7 & 8.9 & 87.4 \\
\hline İngiltere & 10.9 & 13.3 & 75.8 \\
\hline
\end{tabular}

http://ec.europa.eu/eurostat/statisticsexplained/images/4/4f/Distribution_of_persons_aged_16_and_over_ by self-reported long

standing_limitations_in_usual_activities_due_to_health_problems2C_by_sex2C_2016_282529_Health20 17.png

Son 6 ayda sağlık sorunu nedeni ile günlük faaliyetlerde sınırlama olup olmadığı ile ilgili 2015 yılında EUROSTAT’ın Avrupa Birliği ülkeleri sonuçları Tablo 7'de sunulmuştur. 2015 yılında Avrupa Birliği üye ülkeleri "evet, çok sınırlandı" \%7,5, evet sınırlandı \%17,3 hayır sınırlanmadı ortalaması ise \%75,2'dir. Türkiye'de ise 2006-2012 sırası ile \%8,6, \%20,1 ve \%71,6’dır. Avrupa Birliği ülkelerine ait Tablo 7 ile Tablo 8'de Türkiye sonuçları karşılaştırıldığında yine aynı şekilde tüm ülkelerde benzer bir dağ 1 lımın olduğu görülmektedir. 28 AB ülkesi ile Türkiye'de \%7 ile \%10 arasında bir kitle son altı ayda sağlık sorunu nedeni ile günlük faaliyetlerinde "evet çok sınırlama" olduğunu rapor ederken, \%15-\%20 aralığındaki bir kitle “evet oldu” ve \%70-\%75'i ise sağlık sorunundan dolayı günlük faaliyetlerinde bir sınırlama olmadığını belirtmiştir. 
Tablo 8. Sağlık Sorunu Nedeni ile Son 6 Ayda Günlük Faaliyetlerde Sınırlama: 2006-2012 GYK Araştırma Sonuçları: Yıl, Kır-Kent, Medeni Durum, Gelir ve Eğitim Düzeyi, Türkiye

\begin{tabular}{|c|c|c|c|}
\hline & $\begin{array}{c}\text { Evet, Çok } \\
\text { Sınırlandı \% }\end{array}$ & $\begin{array}{c}\text { Evet } \\
\text { Sınırlandı\% }\end{array}$ & $\begin{array}{c}\text { Hayır } \\
\text { Sinırlanmadı\% }\end{array}$ \\
\hline 2006 & 7,6 & 18,5 & 73,9 \\
\hline 2007 & 6,9 & 17,1 & 76,0 \\
\hline 2008 & 7,8 & 20,3 & 71,9 \\
\hline 2009 & 8,6 & 20,4 & 71,1 \\
\hline 2010 & 8,4 & 20,9 & 70,7 \\
\hline 2011 & 8,3 & 19,7 & 72,0 \\
\hline 2012 & 7,6 & 19,2 & 73,2 \\
\hline Kır & 10,0 & 22,6 & 67,4 \\
\hline Kent & 6,6 & 17,6 & 75,9 \\
\hline Erkek & 6,5 & 16,3 & 77,1 \\
\hline Kadın & 9,1 & 22,3 & 68,5 \\
\hline Evli & 3,9 & 6,6 & 89,5 \\
\hline Hiç evlenmedi & 7,6 & 22,0 & 70,4 \\
\hline Eşi Öldü & 26,3 & 39,4 & 34,3 \\
\hline Boşandı & 16,5 & 31,2 & 52,3 \\
\hline Ayrı yaşıyor & 9,4 & 24,3 & 66,3 \\
\hline 1.20 & 14,5 & 23,7 & 61,9 \\
\hline 2. 20 & 10,2 & 21,9 & 67,9 \\
\hline 3.20 & 9,0 & 22,9 & 68,1 \\
\hline 4.20 & 5,5 & 18,0 & 76,5 \\
\hline 5.20 & 2,8 & 13,2 & 84,0 \\
\hline İlkokuldan az & 18,4 & 32,4 & 49,2 \\
\hline İlk ve ortaöğretim & 6,0 & 18,6 & 75,4 \\
\hline Lise ve dengi & 2,6 & 9,9 & 87,5 \\
\hline Üniversite ve + & 2,1 & 8,8 & 89,2 \\
\hline Toplam & 7,9 & 19,5 & 72,7 \\
\hline
\end{tabular}


Türkiye'de herhangi bir sağl1k sorunu nedeni ile son 6 ayda günlük faaliyetlerde aksama olduğunu rapor edenlerin ortalamas1 sıras1 ile 2006'dan 2012'ye 28 Avrupa Birliği ortalamasından \%4 oranında daha fazladır. Türkiye'de anket yapılan fertlerin \%8'i Avrupa Birliği ülkeleri ile aynı oranda "evet, çok sınırlandı" şeklinde ciddi rahatsızlık olduğunu belirtirken 19,5 'i evet sınırlandı şeklinde beyan etmiş ve \%73 ise son 6 ay içinde herhangi bir sağlık sorunundan ötürü günlük faaliyetlerinde herhangi bir aksama olmadığını belirtmişlerdir.

Avrupa Birliği ülkeleri çok farklı sosyo-kültürel ve sağlık sistemleri ile homojen bir yapıya sahip değildir. Avrupa Birliği ülkelerinde liberal, muhafazakâr-korporatist ve sosyal demokratik olmak üzere üç farklı sosyal güvenlik sistemi bulunmaktadır (Anderson, 1990, 1999). İngiltere ve İrlanda da olduğu gibi liberal sosyal güvenlik sisteminde devlet sadece bazı temel sağlık hizmetlerini sunmakta ve bireyler herhangi bir kriz durumunda aileye bağlı olmaktadır ve bu ülkelerde gelir eşitsizliği yüksektir. Muhafazakâr korporatist sosyal güvenlik ve sağlik sistemi kilise ve ailenin etkili olduğu bir sistemdir. $\mathrm{Bu}$ sistemde devlet vatandaşlarının statü ve gelirlerine göre sağlık hizmetlerini garanti altın alır gelir eşitsizliği diğerlerine göre düşüktür. Lüksemburg, İsviçre, Hollanda, Avusturya, Almanya, Belçika ve Fransa muhafazakâr-korporatist sosyal güvenlik sistemi içinde yer almaktadırlar. Sosyal demokratik sistem ise Danimarka, Norveç, İsveç ve Finlandiya'da tatbik edilmektedir ve bu ülkelerde sosyal güvenlik en yüksek düzeydedir. Dolayısı ile sağl1kta eşitsizlik bu ülkelerde çok düşük düzeydedir. Esping Anderson (1990; 1999) bu üçlü modeline Ferrera (1996) ve Bonoli (1997) Akdeniz ülkeleri tipi dördüncü bir sosyal güvenlik modeli ekleyerek İtalya, İspanya, Yunanistan ve Portekiz'deki sağlık uygulamalarını örnek göstermektedir. Bu ülkelerdeki uygulamalarda sosyal güvenlik sistemi gelişmemiştir ve aileye bağımlılık üst düzeydedir. Dört farklı uygulamaya ilave olarak beşinci bir sınıflama ile Doğu Avrupa'da Polonya, Çekya ve Macaristan postsosyalist bir kategoriye dâhil edilmekte ve sağlı sistemi bu ülkelerde daha eşitsiz bir dağılım arz etmektedir. Yapılan araştırmalarda sağlık alanında sosyal demokratik uygulamaların olduğu ülkelerde sağlık hizmetlerinin daha eşit ve nitelikli olduğu ortaya çıkmaktadır. 
Karşılaştırma yapılacak olursa Türkiye bu beş sistem içinde muhafazakâr-korporatist sağlık sistemine benzemektedir fakat net bir görüş ifade etmek için derinlemesine karşılaştırmalar yapmak gerekmektedir. Çünkü her ülkenin tarihi ve kültürel şartları kendi içinde farklı uygulamalara yol açmaktadır. Ayrıca yukarıda incelediğimiz üç değişken açısından bakıldığında farklı sistemler arasında net bir sınırın çizilmesi zordur. Fakat hangi sistem olursa olsun gelir ve eğitim düzeyi bütün sistemlerde en etkili faktördür. Sistemler arasında farkı tespit edebilmek için daha çok subjektif ve objektif sağlık verilerine ihtiyaç vardır. Danimarka ve İsveç gibi kuzey ülkelerinde güçlü sağlık sistemi vardır. Akdeniz ve eski Doğu Avrupa ülkelerinin şartları daha farklıdır. Ayrıca pek çok $A B$ ülkesinin nüfusu 10 milyonun altındadır. Az nüfuslu birkaç ülke dışında \%25-\%30 arasında değişen bir kitle son 6 ayda sağlık sorunu nedeni ile günlük faaliyetlerinde aksama olduğunu bildirmiştir. 


\section{DEĞERLENDİRME}

Subjektif algılara göre sağlık durumu, kronik hastalıklar ve sağlık sorunu nedeni ile günlük faaliyetlerde sınırlanma ortalamaları değerlendirildiğinde incelenen ülkeler açısından insanların sağlık-hastalık deneyimleri birbirine yakındır. OECD, Avrupa Birliği ve Türkiye'de son 10 yıllık bir zaman diliminde insanların \%60-70'i sağlık durumunun "iyi” olduğunu, \%20-25'i sağlık durumunun "fena olmadığını", \%810’u “kötü” ve \%2-3’ü de sağlık durumunun “çok kötü” olduğunu ifade etmektedir.

EUROSTAT ve TÜİK'in 2006-2016 yılları arasında yaptıkları GYK anketlerinde kronik hastalıkların dağılımında $\mathrm{AB}$ ülkeleri ve Türkiye'de insanların \%30-\%32'si kronik hastalığının olduğunu rapor etmişlerdir. Ancak 28 üyeli Avrupa Birliği ülkelerinin yarısında kronik hastalıkların oranı \%40'ın üzerindedir. Avrupa Birliği ve Türkiye'de sağlık sorunu nedeni ile son altı ayda günlük faaliyetlerinde çok sınırlanma olduğunu rapor edenler $\% 7$ ile $\% 9$ arasındadır.

Özetle, OECD, Avrupa Birliği ve Türkiye mukayese edildiğinde günümüz şartlarında yaşayan insanların ortalama \%30-32'si kronik hastalıklarının olduğunu ve \%10-13'ü de sağlık durumlarının iyi olmadığını ifade etmişlerdir. Bu ülkeler tarih, kültür ve sosyo-ekonomik yönden farklı ülkelerdir. Ancak bu farklılığa rağmen sağlık-hastalık durumları sonuç itibarı ile birbirine yakın oranlarda benzer yapısal bir süreç izlemektedir. Modern tıp son yüz yılda enfeksiyon ve bulaşıcı hastalıkları tedavi etmeyi başarmıştır ve ortalama yaşam her ülkede yükselmiştir. Çok yoksul ülkeler hariç diğer ülkelerde ortalama yaşam süresi en fazla 10-12 yıl fark etmektedir. Geçmiş yüzyıllardaki enfeksiyon ve bulaşıcı hastalıkların yerini modern dünyada kronik hastalıklar almıştır. Dolayısı ile sağlık alanında ülkelerin karşılaştırılmasındaki farklar kadar ortak özelliklerin neler olduğunu araştırmak sağlik sosyolojisinde üzerinde durulması gereken bir meseledir.

Yüksek gelirli ülkelerde yaşayan insanlar da daha düşük gelirli ülkelerdekiler ile yakın ve hatta bazı kronik hastalıklara daha ileri düzeyde yakalanmaktadır. Yüksek gelirli ülkelerle daha düşük gelirli ülkeler arasındaki temel fark tedavi imkânlarının ileri düzeyde olması ve yüksek eğitim düzeyi nedeni ile zengin 
ülkelerde insanlar hasta olsalar bile bu hastalıklar uzun vadede kontrol altına alınarak ortalama yaşam süresi 10-12 yıl daha fazla uzamaktadır. Örneğin, Fransa ve İspanya'da ortalama yaşam süresi 83 yılken rapor edilen kronik hastalıklar oldukça yaygındır. Güney Kore ve Japonya'da yaşayan insanların \%70’i sağlık durumunun iyi olmadığından şikâyetçidir; fakat refah düzeyinin yüksek olması ortalama yaşam süresini 83 yaşa kadar çıkarmaktadır. Kısacası, ömrün uzun olması sağlıklı olmak anlamına gelmemektedir ve bu nedenle de 'modern tıp hayatı değil ölümü uzatır' denilmektedir. Günümüz şartlarında 70 yaş sonrası, istisnalar hariç çoğunluk için aynı zamanda hastalıklarla yaşamak ve sıklıkla doktor tedavisi altında bulunmaktır.

Türkiye, son 10 yıllık bir sürede sağlık durumu, kronik hastalıklar ve günlük faaliyetlerde sınırlamada OECD ve AB ülke ortalamaları ile örtüşmektedir. İncelenen üç değişken açısından Türkiye'de nüfusun \%65’i sağlık durumlarının iyi ve çok iyi olduğunu, bir diğer \%20'si fena olmadığını, \%13’ü kötü ve diğer \%2'si de çok kötü olduğunu dile getirmiştir. Kronik hastalıkların ise \%30,9 ve sağlık sorunu nedeni ile son altı ayda günlük faaliyetlerde sınırlanmada evet, çok sınırlandı $\% 7,8$, evet sınırlandı $\% 19,5$ ve sınırlanmadı ise $\% 73$ 'dür.

Ancak, ülkelerin genel ortalamaları demografik ve sosyo-ekonomik faktörler ile detaylandırıldığında dağılımların her sosyo-ekonomik kategoride eşit olmadığı görülmektedir. Bütün göstergeler kırlara göre kentlerin \%10 daha fazla oranda olumlu olduğunu, cinsiyet açısından kadınların daha uzun yaşamasına rağmen dünyanın her yerinde olduğu gibi Türkiye'de de daha erken ölen erkeklerin daha uzun yaşayan kadınlar kadar hastalık tecrübesi yaşamadıklarını göstermektedir. Fakat Türkiye bağlamında cinsiyet tek başına güçlü bir açıklayıcı faktör değildir. Avrupa Birliği ülkeleri ile Türkiye arasında cinsiyet bakımından algılanan sağlık durumunda anlamlı bir fark bulunmamaktadır. Türkiye şartlarında incelenen değişkenler açısından en büyük fark oran olarak sırası ile medeni durum, eğitim ve gelir düzeyinde gözlemlenmektedir. Eğitim düzeyi ilkokuldan daha az bireyler 60 yaş üzerindedir ve gelir diliminin en altında yer almaktadırlar. 
Bulgular, Türkiye'de insanların kendilerini sağlıklı hissetmelerinde evliliğin psikolojik, sosyal ve ekonomik yönden olumlu işlev gördügünü desteklemektedir.

İki binli yılların başında Türkiye'de ortalama yaşam beklentisi 70 yaşken 18 yılda 8 yaş artarak 78'e yükselmiştir. Ortalama yaşam 2018 yılı itibarı ile erkeklerde 75,3, kadınlarda ise 80,7'dir. 18 yıl gibi kısa bir zaman diliminde ortalama ömrün 78 yaşa kadar ulaşması sağlıkta büyük dönüşümlerin yaşandığını göstermektedir. OECD, Türkiye' de sağlıkta olumlu dönüşümleri ayrıntıları ile inceleyip yayınlanmaktadır. Ancak, Türkiye' de sağlıkta dönüşüm tam olarak istenen düzeyde değildir ve AB ülkelerine göre hastane, doktor ve sağlık hizmetleri altyapısında $\mathrm{AB}$ ülkelerinin gerisinde yer almaktadır. Pek çok $\mathrm{AB}$ ülkesine göre büyük bir nüfusu olan Türkiye' nin daha çok nitelikli hastaneye, doktora ve sağl1k personeline ve buna ulaşacak imkânların arttırılmasına ihtiyacı vardır.

Tüm dünyada gelir artmakta bulaşıcı hastalıklardan ölümler azalmakta ve eş zamanlı olarak toplumlar yaşlanmaktadır. İnsanların ömrü uzadıkça kronik hastalıkların görülme sıklığı da artmaktadır. Dünya genelinde kronik hastalıklardan ölümlerin yarısı 70 yaş altındadır. Türkiye'de sağlık harcamalarının büyük bir kısmı (\%60-80) bu hastalıkların tedavisi için yapılmaktadır. Türkiye yaşlanmakta olan nüfusu ve değişmekte olan yaşam şekli sebebi ile kronik hastalıklarla mücadeleye hazırlıklı olmalıdır. Kronik hastalıklar bütün dünyada halk sağlığının en önemli sorunu haline gelmiştir. Türkiye yaşlanmakta olan nüfusu ve değişmekte olan yaşam şekli sebebi ile kronik hastalıklarla mücadeleye hazırlıklı olmalıdır. 


\section{SUMMARY}

In this article, based on subjective perceptions of individuals, health status, prevalence of long standing chronic disease and limitation in daily activities due to health problems are analyzed in Turkey, European Union and OECD countries. Income and Living Conditions and better life index data were used for the analyses. In the first part of the article, researches about the subject and the results of research about the social origins of health-disease are summarized and objective and subjective health measurements are emphasized. In the second part, the data and methods are described and in the last chapter, the health and disease status and perception in Turkey, the European Union and OECD member countries are evaluated by summarizing analyzes.

Considering the averages of daily activities due to health status, chronic diseases and health problem, health-disease experiences of people are close to each other in terms of the countries examined. In the last 10 years, $60-70 \%$ of people stated that their health was "good", 20-25\% said that their health was "fair", 8 $10 \%$ of them said "bad" and 2-3\% stated their health status as "very bad" in OECD, European Union and Turkey.

In the surveys on Income and Living conditions conducted by EUROSTAT and TÜIK between 2006-2016, it was found that $30 \%-32 \%$ of people in the EU countries and Turkey reported to have chronic diseases. However, the rate of the chronic diseases in half of the countries of the European Union with 28 members is more than $40 \%$. In the European Union and Turkey, those who reported that there was a very limited daily activities in the last six months due to health problems, is between $7 \%$ and $9 \%$. These countries are different countries in terms of history, culture and socio-economic aspects. However, despite this difference, health-disease conditions follow a similar structural process with close proportions.

In the last decade, Turkey's state of health is consistent with OECD and EU averages chronic in diseases and limitations in daily activities. In terms of three variables examined, $65 \%$ of Turkey's citizens said that their health condition was good and very good; $20 \%$ said that it was not bad, $13 \%$ said it was bad and $2 \%$ 
stated that it was very bad. $30.9 \%$ of of the chronic diseases and limitation in daily activities in the last six months due to health problems; "yes, very limited" was 7,8\%, "yes, limited" was 19,5\% and "not limited" was $73 \%$.

However, it is also a fact that when the general averages of countries are detailed with demographic and socio-economic factors, the distributions are not equal in every socio-economic category. All indicators show that cities are more positive by $10 \%$ than rural areas, although women live longer in terms of gender, in Turkey as everywhere else in the world, it shows that men who died earlier did not experience disease as much as women who lived longer. But gender alone is not a strong explanatory factor in the context of Turkey. There is no significant difference between European Union countries and Turkey in the perceived health status in terms of gender. In terms of the variables examined conditions in Turkey, the biggest difference seen in ratios is respectively marital status, education and income levels. The individuals whose education level is less than primary school are over 60 years old and they are at the bottom of the income segment. The findings support that marriage acts positively in psychological, social and economic terms in people's feeling themselves healthy in Turkey. 


\section{KAYNAKÇA}

Adak N. (2015). Sağlık Sosyolojisi Kadın ve Kentleşme, İstanbul: Birey Yayıncılık.

Adak, N. (2018). Sağlık Sosyolojisi, Atatürk Üniversitesi Yayınları.

http://www.egitim.club/wp-content/uploads/2017/06/Sa\%C4\%9F1\%C4\%B1k-Sosyolojisi-17.pdf.

Akşit, B., Akşit, B. (1989). Socio Cultural Determinants of Infant and Child Mortality. Social Sciences and Medicine, 28 (6): 571579.

Alptekin, D. (2018). Sağlığın Sosyal Belirleyicileri. Nurşen Adak (Ed.), Sağlık Sosyolojisi içinde (s.7895). http://www.egitim.club/wp-content/uploads/2017/06/Sa\%C4\%9Fl\%C4\%B1k-Sosyolojisi-17.pdf .

Aytaç, Ö., Kurdaş, M. Ç. (2015). Sağlık-Hastalığın Toplumsal Kökenleri ve Sağlık Sosyolojisi. Firat Üniversitesi Sosyal Bilimler Dergisi, 25 (1): 231-250. http://dergipark.gov.tr/download/articlefile/157413.

Baloğlu, B. (2006). Sağlık ve Hastalık \& Ekonomik ve Sosyolojik Bakış Açısıyla. Der Yayınları.

Blaxter, M. (2004). Health. Polity Press.

Bolsoy, N., Sevil, Ü. (2006). Sağlık Hastalık ve Kültür Etkileşimi. Atatürk Üniversitesi Hemşirelik Yüksek Okulu Dergisi, 9(3):78-87, http://dergipark.gov.tr/download/article-file/29326.

Brown, D. (2006). Surveys of Living Conditions (SLCs): Reported Health and Poverty in the Caribbean. Social and Economic Studies, 55-4: 55-77.

Browne, K. (2014). Sosyolojiye Giriş. İ. Kaya (Çev.). İstanbul: Say Yayınları.

Center for Desease and Control Prevention, (2017). New CDC Report: More than 100 Million Americans Have Diabetes or Prediabetes. https://www.cdc.gov/media/releases/2017/p0718-diabetesreport.html

Cirhinlioğlu, Z. (2012). Sağlık Sosyolojisi. 3. Basım, Ankara: Nobel Akademik Yayıncılık.

$\mathrm{SAD} / \mathrm{JSR}$

Cilt / Volume 22 Sayı / Number 1 
Çukur, A., Bekmez, S. (2012). Türkiye'de Gelir Eşitsizliği ile Algılanan Sağlık Statüsü Arasındaki Ilişkinin Ulusal Sağlık Anket Verileri ile İncelenmesi. İktisat, İşletme ve Finans, 27 (3): 73-104.

Dahlgren, G., Whitehead, M. (1991). Policies and Strategies to Promote Social Equity in Health. Stockholm: Institute of Futures Studies.

Ekonomik İşbirliği ve Kalkınma Örgütü (OECD). (2017). Better Life Index. http://www.oecdbetterlifeindex.org/topics/health/

EUROSTAT. (2016). Distribution of Persons Aged 16 and Self Perceived Health by Sex. https://ec.europa.eu/eurostat/statisticsexplained/images/e/e5/Distribution of persons aged 16 an d over by self-perceived health status\%2C by sex\%2C $2016 \% 28 \% 25 \% 29$ Health2017.png

EUROSTAT. (2010-2016). People Having a Long-Standing Illness or Health Problem by Sex, Age and Educational Attainment. http://appsso.eurostat.ec.europa.eu/nui/show.do?dataset=hlth_silc_05\&lang=en

EUROSTAT. (2016). People Having a Long-Standing Illness or Health Problem by Sex, Age and Educational Attainment. https://ec.europa.eu/eurostat/statisticsexplained/images/e/e5/Distribution of persons aged 16 an d over by self-perceived health status\%2C by sex\%2C $2016 \% 28 \% 25 \% 29$ Health2017.png

Gataulinas, A., Bancevica, M. (2014). Subjective Health and Subjective Well-Being - The Case of EU Countries. Advences in Applied Sociology, 4:212-223. https://file.scirp.org/pdf/AASoci 2014092614575716.pdf

Giddens, A. (2005). Sosyoloji. Cemal Güzel (Yayına Haz.). Ankara: Ayraç Yayınevi.

Goryakin, Y., Suhrcke, M., Rocco, L. Bayard, R. and Mckee, M. (2013). Social Capital and Self Reported General and Mental Health in Nine Former Soviet Union Countries. Health Economics Policy and Law. Cambridge University Press. https://researchonline.lshtm.ac.uk/705754/1/social\%20capital.pdf

Gönç, Ş. T. (2013). Toplumsal Eşitsizlikler ve Sağlık. O. Elbek (Ed.), Kapitalizm Să̆lığa Zaralıdır içinde (s.57-71). İstanbul: Hayy Kitap.

Güven, S. (2014). Türkiye' de Sağlık Sosyolojisi Çalışmaları. Sosyoloji Dergisi, 3 (29): 127-164. 
Hui, Z., Thomas, P. (2013). Marital Status, Self-Rated Health, and Mortality: Overestimation of Health or Diminishing Protection of Marriage? Journal of Health and Social Behavior, 54 (1): 128-143.

İnanç, N., Hatipoğlu, S., Yurt, V. ve diğg. (1999). Hemşirelik Esasları. 4. Baskı. Ankara: Damla Matbaacılık Ltd. Şti.

Kaisla, E., Joutsenniemi, T., Seppo, V., Koskinen. (2006). Official Marital Status, Cohabiting, and SelfRated Health-Time Trends in Finland, 1978-2001. European Journal of Public Health, 16 (5): 476-483.

Kasapoğlu, A. (1999). Săglık Sosyolojisi, Ankara: Sosyoloji Derneği Yayınları.

Kasapoğlu, A. (2001). Güncel Sosyal Sorunlar ve Sağlık. Toplumbilim Dergisi Sağlık Sosyolojisi Özel Sayısı, 13, 11-22.

Kasapoğlu, A. (2008). Madalyonun Iki Yüzü: Hastalık ve Sağlık. Ankara: Phoeniks Yayınevi.

Kızılçelik, S. (1996). Türkiye ’nin Sağlık Sistemi Bir Medikal Sosyoloji Denemesi. İzmir: Saray Kitabevleri.

Küçükusta A. R. (2011). Bir İki Üç Tip. İstanbul: Hayy Kitap Yayıncılık.

Levi, B. (2017). Perceived Health Status in a Comparative Perspective: Methodological Limitations and Policy Implications for Israel. Israel Journal of Health Policy Research, 6: 2.

Maheswaran, H., Kupek, E., Petrou, S. (2015). Self-Reported Health and Socio-Economic Inequalities in England, 1996-2009: Repeated National Cross-Sectional Study. Social Science and Medicine, 136: 135-146.

Manavgat, G., Çelik, N. (2017). Sağlık Düzeyinin Belirleyicilerine Yönelik Mekansal Bir Analiz: Türkiye İBBS-3 Örneği. Sosyoekonomi, 25 (34): 53-67.

Marmot, M., Wilkinson, R. G. (1999). Social Determinants of Health. Oxfort University Press.

Matrai, K. N. Z. (2015). Subjective and Objective Indicators in the Reserach on Health Status. Journal of Human Support \& Exercise, 11: 207-217.

Özen, S. (1993). Sosyolojide Bir Alan: Sağlık Sosyolojisi ve Sağlık-Toplumsal Yapı Ilişkileri. Ege Üniversitesi Edebiyat Fakültesi Yayınları, 4: 73-85. 
Palloni, A., Pinto-Aguirre, G., Palaez, M. (2002). Demographic and Health Conditions of Ageing in Latin America and the Caribbean. International Journal of Epidemiology, 31: 762-771. https://pdfs.semanticscholar.org/b582/8c88ac6f7d0939b8f3bd2a9d5399ea76e941.p

Romaniuk, J. (2014). Subjective and Objective Health of the Population Aged 50+ and Welfare State Regimes in 16 European Countries. International Journal of Management and Economics, 39: 82107.

Şantas, F. (2017). Yoksulluğun Sağlık Statüsü ve Sağlık Kullanımı ile İlişkisi. Iğdır Üniversitesi Sosyal Bilimler Dergisi, 13: 545-591.

Tan, Z., Shi, F., Zhang, H., Li, N., Xu, Y. and Liang, Y. (2018). Household Income, Income Inequality and Health-Related Quality of Life Measured by the EQ-5D in Shaanxi, China: A Cross-Sectional Study. International Journal of Equity in Health, 17: 32.

Terceira, A. B., McQuillan, J. (2018). Self-Rated Health Trajectories among Married Americans: Do Disparities Persist over 20 Years? Journal of Aging Research, Volume 2018.

T.C. Sağlık Bakanlığı. (2008). Kronik Hastalıklar Risk Faktörleri Sağlığın Teşviki ve Geliştirilmesi Sempozyumu. 13 - 14 Kasım 2008, Ankara. https://sbu.saglik.gov.tr/Ekutuphane/kitaplar/t13.pdf

T.C. Sağlık Bakanlığı (2018). Türkiye'de Kronik Hastalıklar ve Risk Faktörleri Sıklığı Çalışması. https://sbu.saglik.gov.tr/ekutuphane/kitaplar/khrfat.pdf

Tecim, E. (2016). Sağlık Sosyolojisi. Konya: Çizgi Kitapevi.

Turkdoğan, O. (1966). Toplumsal Yapı ve Sağllk-Hastalık Sistemi. İstanbul: IQ Kültür-Sanat Yayıncılık.

Liderler Zirvesi: Uluslararası Diyabet. (2013). Türkiye'de ve Bölge Ülkelerinde Diyabet Sorunu. http://www.diabetcemiyeti.org/c/turkiye-de-ve-bolge-ulkelerinde-diyabet-sorunu

Türkiye İstatistik Kurumu. (2012). Gelir ve Yaşam Koşulları Araştırması Mikro Veri Seti. Ankara: TüİK Yayınları.

Türkiye İstatistik Kurumu. (2013). Gelir ve Yaşam Koşulları Mikro Veri Setleri: 2006-2013. Ankara: TÜİK Yayınlar1. 
Türkkan, A., Aytekin, H. (2009). Socioeconomic and Health Inequality in Two Regions of Turkey. Journal of Community Health, 34: 346-352.

Wilkinson, R. G. (1997). Socioeconomic Determinants of Health: Health Inequalities: Relative or Absolute Material Standards? British Medical Journal, 314 (7080): 591-595.

World Health Organization. (2008-2013). Action Plan for the Global Strategy for the Prevention and Control for Noncommunicable Deseas. Geneva: WHO Press.

Wu, S., Wang, R., Zhao, Y. (2013). The Relationship between Self-Related Health and objective Health Status: A Population Based Study. BMC Public Health, 13:320. 